\title{
PUBLIC PARTICIPATION IN URBAN NOISE PREVENTION: THE CASE OF A HUNGARIAN TOWN
}

\author{
Z. BAROS ${ }^{1} \&$ L. DÁVID ${ }^{2}$ \\ ${ }^{1}$ Institute of Agroinformatics and Rural Development, Károly Róbert College, Gyöngyös, Hungary. \\ ${ }^{2}$ Department of Tourism and Regional Development, Károly Róbert College, Gyöngyös, Hungary.
}

\begin{abstract}
The so-called 'soft factors' are playing an increasing role in urban planning. Alternative strategies based on these factors can include bottom-up initiatives in which citizens intend to find solutions to noise-related problems in their settlement through their participation and in accordance with their requirements. This paper intends to give a brief introduction to the role of individuals regarding their participation in such programmes, based on the literature available and the results of a questionnaire survey carried out in the Town of Debrecen (East Hungary). The results of the survey indicated that the overall picture of the residents' opinions on noise pollution is rather contradictory: they basically seem to perceive the impacts and the relevance of this issue, however, in general, the respondents did not recognise their own roles in resolving the problem itself - neither as 'polluters' nor as 'endurers'.

Keywords: liveability, mental infrastructure, noise nuisance, noise prevention programmes, public participation, sustainable urban development.
\end{abstract}

\section{INTRODUCTION}

Noise nuisance is one of the most severe problems impacting urban residents. According to estimations by the OECD, more than half of the citizens in Europe live in noisy environments and about one-third of them are exposed to high noise levels at night causing sleep disturbances [1]. Noise management is gaining increasing prominence as a factor in the protection of the urban environment today. And, as a consequence, is now an integral part of all environmental impact assessments [2]. Environmental noise is recognised as an indicator of the quality of the environment [3] and integrated urban development strategies place great emphasis on the management of noise-induced environmental problems. Successfully combating noise pollution thus represents a major step towards the establishment of an urban environment that provides an adequate quality of life [4].

Humankind seeks better quality and more secure housing. On the basis of the available literature, it is quite difficult to define better quality housing. One aspect, however, is clear: a healthy physical or built environment is a necessary precondition for the viability of settlements [5]. The condition of the environment (i.e. air, soil, water, noise, etc.) is, in addition to the quality of life, one of the main factors influencing urban tourism [6], a sector considered to be a major priority in the economic development of the Town of Debrecen, which is the focus of this study.

\section{SUSTAINABLE URBAN DEVELOPMENT, QUALITY OF LIFE AND NOISE NUISANCE}

According to Juhary-Koroknay [7], residents' level of comfort in a given district depends on the following factors: protection of the individuals including protection against noise impacts, adequate living conditions, and the establishment of symbiosis. The first factor, namely, the desire for a peaceful and quiet residential environment or an improved level of acoustic comfort motivates the majority of intra-urban movements in residential areas. This had been a decisive factor already in the late 1980 s, accounting for $15 \%$ of movements from the city centre of Cologne to its environs [8]. 
The specific 'noise characteristics' of a residential area and workplace [9] are created jointly by various sources of noise. Most public opinions on the environment of residential areas and factors influencing property prices (i.e. the quality of the living environment, the property's age and type of construction, traffic, green areas) are directly or indirectly linked to the noise characteristics of the area [10]. The impact of such physical parameters on leisure, recreation and other activities can greatly influence the image of the given district. It is, along with the social milieu of the built environment (status and incomes of the residents), reflected as a complex indicator by property prices. This is also the case for tourism destinations where, due to the negative image among visitors resultant from the increasing noise pollution impeding relaxation and recreation, the given area becomes less attractive [11]. Such adverse processes may be manifested in an increasing rate of removal of residents as well as in a decrease of property prices (i.e. the devaluation of properties) or, for tourism destinations, in a reduced number of visitors, or even in a loss of prestige of the given area. However, a built environment including elements of the opposite, i.e. a built environment that includes elements of the physical environment (among which, silence can also be mentioned), is more likely to be favoured compared to any not including natural elements [12], as is also claimed by many authors.

Having the above summarised, the overall view of the acoustic comfort or noise conditions can contribute, in a broader sense, on the characteristics of the noise conditions can contribute to the district's image, its attractiveness and the property prices and influences perceptions of liveability [4]. This last is one of the four main development objectives of the World Bank's new urban strategy, developed at the turn of the millennia [13], whose strategic central objective is support of sustainable urban development. Most of the criteria focus on social sustainability with a lesser concern for sustainability of environmental conditions. Comparing these to the factors applied to benchmark social sustainability (i.e., Sustainability Value Map) developed by Butters [14], it can be concluded that, in addition to security, the only other common factor is 'quality of life accessible for all' (Fig. 1).

By the late 20th century, environmental approach has undergone changes, settlements all over Europe have become more opened, with a significant increase in enforcing ecological aspects and, in general, sensitivity to the way of using the environment. In the future, just due to the focus put on the problems of civilization and urbanisation development, the role of environmental quality will likely to be more relevant. Not only the aesthetic quality of the environment will be in the focus of the society's interest but also (among others) primarily, the improvement of the state of environment [16].

The significant increase in environmental noise related awareness and its impacts in recent years can be the result of the fact that environmental problems in the past decade have been transferred from the industry to people's homes [17], having been exposed to their costs manifold influencing their everyday activities. However, in urban noise related research in recent years, the emphasis has been removed from noise abatement to noise prevention environmental planning [18], by this, integrating the methodologies of psychology, noise quality studies and social sciences.

Some authors (see e.g. [19]) emphasize the importance of public opinions, subjectivity in the process of elaborating environmental impact assessments. Others [20] esteem individual approach as a basis of informal decisions made in order to achieve well-being, improved health conditions of the inhabitants as part of the human-environment-human interrelationship.

Having the above as well as the fact according to which environmental noise is now assessed as an indicator of the quality of environment [3] taken into account, the estimation of realistic feasible demands and their fulfillment is relevant [21], especially as in the development policies of settlements ('proactive') community actions gain an increasing role [22]. Public involvement into the development of the environmental quality of given regions is also listed among the recommendations of the preamble of the Leipzig Charter [23]. 


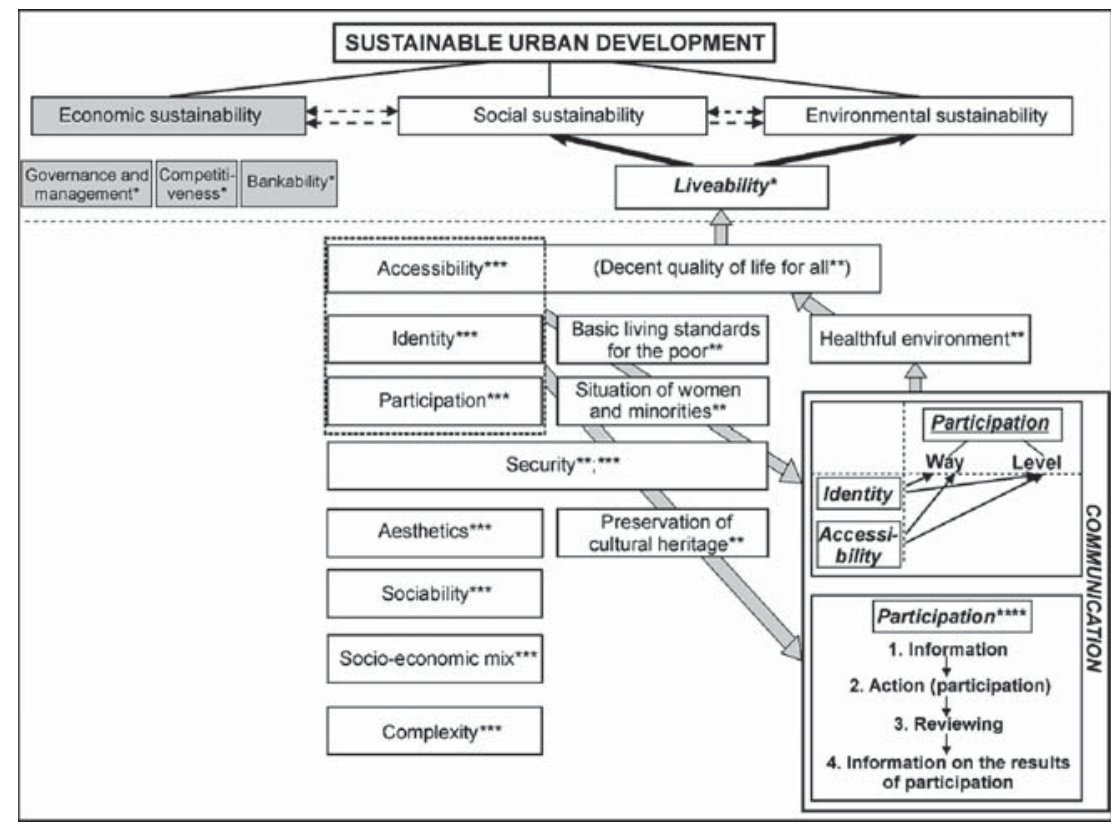

Figure 1: Social dimensions of sustainable urban development and its relationship to public participation in solving environmental problems [4]. *Dimensions of sustainable urban development according to the World Bank [13]; ** Main development measures to be taken in order to achieve 'liveability', according to the World Bank [13]; ***Social dimensions of sustainable development according to Butters [14]; ****Steps of public participation in the management of noise nuisance related problems (modified after Bonacker [15]).

Questionnaire surveys with a high number of respondents can be useful for urban planning and development in indicating areas where the implementation of noise prevention measures are most demanded by the inhabitants as well as making the selection of the most effective and economic actions to be implemented. Such results as the basis for social initiatives that according to Bulla [24] can be the sole solution to noise pollution caused local problems. Noise is an environmental problem known since ancient times, influencing the comfort feeling of urban inhabitants with impacting not only our everyday lifestyle (sleeping, working, communication, etc.) but also the health status of citizens both in a direct and an indirect way (hearing damage, high blood pressure, etc.). Management (prevention and mitigation, or abatement) is an apparently relevant task in order to facilitate better, more liveable environment for the residents as well as, in many cases, to establish necessary conditions required for everyday life (healthy living environment). These data can provide important guidelines in developing urban environmental programmes, which in the long run, can address relevant urban environmental problems at the local level and can implement efficient public participation [10].

\section{METHODS}

The following sections include a review of the roles of three potential actors (i.e. the municipality, civil organisations and the individuals) in sharing responsibilities for noise pollution abatement and a discussion of the results of a questionnaire survey of the opinions of residents on noise nuisance, which was conducted in the Town of Debrecen (East Hungary) [10]. 
Table 1: Main topics of the questionnaire applied [10].

\begin{tabular}{|c|c|c|c|}
\hline & Dwelling & Workplace & Street \\
\hline The level of noise-related disturbance & $\checkmark$ & $\checkmark$ & $\checkmark$ \\
\hline $\begin{array}{l}\text { The source of noise judged to be the most relevant } \\
\text { and most disturbing }\end{array}$ & $\checkmark$ & $\checkmark$ & $\checkmark$ \\
\hline Disturbances caused by traffic & $\checkmark$ & $\checkmark$ & $\checkmark$ \\
\hline $\begin{array}{l}\text { The time and duration of the highest and lowest } \\
\text { disturbance/the period the situation exists }\end{array}$ & $\checkmark$ & $\checkmark$ & \\
\hline $\begin{array}{l}\text { The impacts of noise-related disturbances on the life } \\
\text { of the respondents }\end{array}$ & $\checkmark$ & & \\
\hline The noisiest locations of the town & $\checkmark$ & & \\
\hline Noise nuisance and abatement at the workplaces & & $\checkmark$ & \\
\hline The health impacts of noise & $\checkmark$ & & \\
\hline Possibilities for noise mitigation and the measures taken & $\checkmark$ & & \\
\hline
\end{tabular}

The survey included questions (altogether 34 in 9 main sections) on the type and level of disturbance caused by noise as experienced at the respondent's home, workplace and in the street and where in the town the highest noise levels were experienced. Questions were also asked about the most important sources of noise emissions, and on the level of noise pollution contributed by traffic. The time and duration of noise nuisance and potential ways of eliminating the existing problems were included in the set of questions (Table 1).

A sample of 909 respondents was selected from typical built-up districts throughout the town, covering its area. In total, 169 streets were classified, partly by studying transport networks and partly from our own experience, into three categories by the intensity of road traffic (with high, medium and low traffic) and their proximity to other sources of noise (railway, industrial facilities, etc.).

\section{RESULTS}

The town can be described as one of the Hungarian settlements with (i) its residential area crossed by several national roads; (ii) only a section of bypass roads built; (iii) a dense built-up pattern; (iv) a structure of its residential area evolved before the revolutionary development took place in motorization, thus with its road network due to the increased road traffic failing to meet the present demands. Among the various sources of noise, and within them transport, road traffic has the impact spreading to the greatest extension of residential area and to the highest number of inhabitants (i.e. it is one of the most frequent sources of noise-related complaints) [25].

\subsection{Sources of noise}

From the results of the questionnaire survey, it is seen, that road traffic is the most disturbing sources of noise. This is the most dominant in the streets with slightly higher noise nuisance values observed at the dwellings (Fig. 2). For the latter one it is noticeable that no significant difference is indicated in opinions of residents living in streets with various levels of traffic. The impact of other ways of transport and sources of noise is much less predominant with among the latter ones (i.e. non-traffic induced sources of noise); machines working in the neighbouring areas are worth mentioning. Here, it should be noted that the apparent noise nuisance caused by them can be regarded as temporary, unlike the repeated or permanent character of all other sources of noise. 


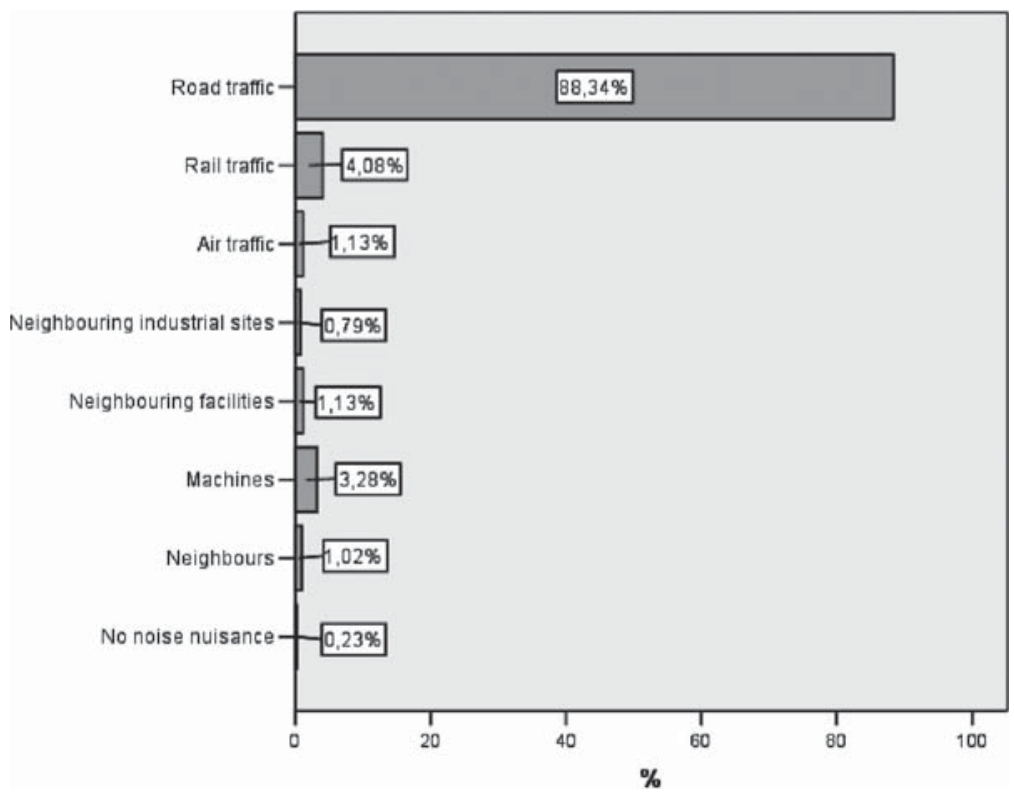

Figure 2: Sources of noise at the homes of the respondents (\%).

The total figures of $93.55 \%$ can be regarded high as previous studies revealed that 'only' $77 \%$ of the respondents specified traffic (all types of traffic altogether) as the main source of noise nuisance in various towns of Hungary [26]. It is also a solemn data that only a minor percentage of the respondents $(0.23 \%)$ indicated not being exposed to noise nuisance at their homes. Furthermore, in addition to the noise nuisance experienced at the dwellings, for about one-fifth of the respondents, workplace noise is also a significant factor.

Road-traffic induced noise nuisance is primarily linked to noise emitted by heavy vehicles $(51.5 \%)$ in the town, whereas more than one-fifth of the respondents $(22.8 \%)$ are disturbed by traffic in general. The impact of public transport as well as nuisance caused by smaller vehicles are lower, however, they are still represented in the responses with a share exceeding $10 \%$.

It was concluded that among the environmental impacts of road traffic, the most important was noise nuisance $(26.1 \%)$. In addition, dust and air pollution from traffic were also indicated as problems.

\subsection{Level of disturbance}

The level of disturbance due to noise propagation proved results that had been expected, i.e. noise nuisance is the largest among those living in streets with heavy traffic. Among these, the respondents' sensitivity to minor noises can also be observed. Only $26.58 \%$ of the respondents reported being not disturbed by noise experienced at their homes, with $40.48 \%$ finding it sometimes disturbing and the remaining ca. 33\% generally or highly disturbing (Fig. 3).

As reflected in the public opinions, exposure to noise is the highest at streets with heavy and medium traffic, whereas for residents of streets with low traffic this is less permanent in time. The highest proportion, $14.9 \%$ of them, claimed having got accustomed to this (major) noise nuisance, rate of which is somewhat higher for those residing in the town centre. 


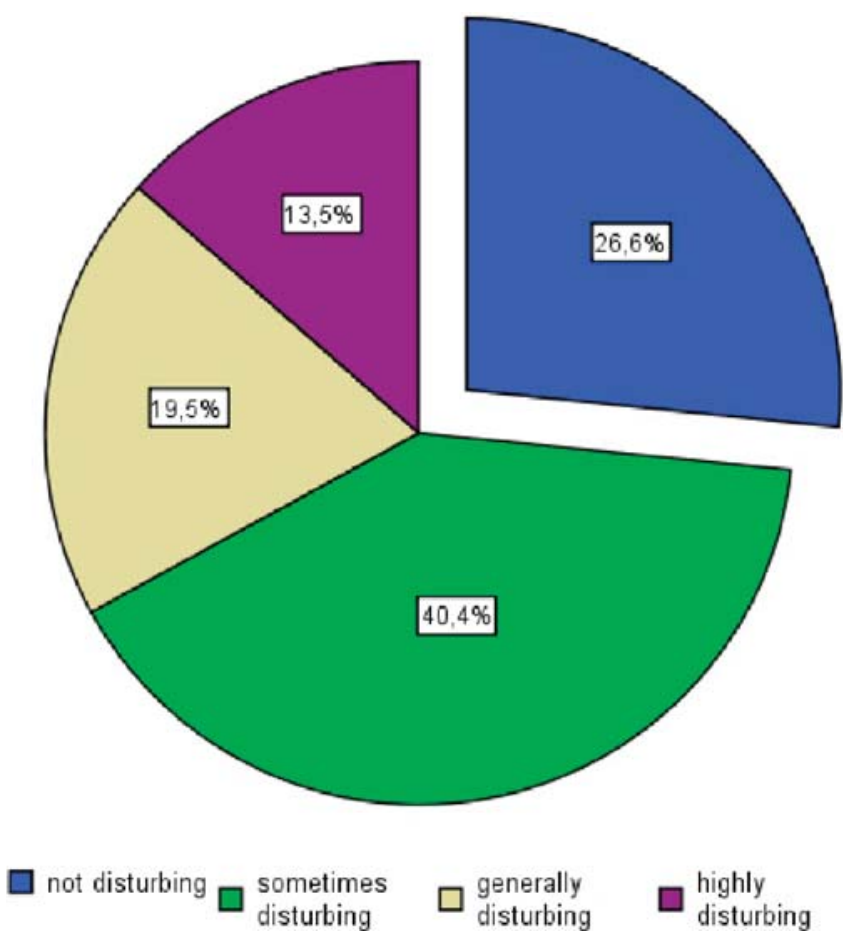

Figure 3: Opinions on noise disturbance experienced at the residents' homes (\%).

General nuisance is experienced at the highest level for the age groups of 41-50 years and above 60 years (45 and 40 respondents), high disturbance at the age group of those above 60 years (43 respondents). The higher tolerance of the younger generation is well indicated by the leading role of the age group of 21-30 years regarding the categories 'sometimes disturbing and not disturbing' (81 and 61 respondents). Although such cases are indicative, regarding the connection between noise nuisance and age, no general conclusions can be drawn from this sample - the Pearson correlation coefficient has a value of 0.202 referring to a low degree of correlation. Regarding sex distribution, it can be claimed that women are somewhat more susceptible to noise.

The value of correlation coefficient for the level of disturbance experienced at homes and general sensitivity to noise is 0.591 , indicating a moderate degree of correlation.

\subsection{Time and duration}

Most of those living in the town found the periods between 6 a.m. and 10 a.m. and between 10 a.m. and 6 p.m. the least endurable and ca. $25 \%$ of the respondents have to cope with the noise propagation at least 5 hours daily. As far as the time and duration are concerned, the town's Central district is the least favourable area. This situation has been the case for $70 \%$ of those living in the town for at least 5-10 years. The overall view is somewhat more propitious in the Northern District where half of the respondents reported to be have been coping with the above for 1-4 years.

Basically similar tendencies can be observed for those residing at streets with medium and low traffic. In the case of those employed, to this noise nuisance experienced at their workplaces and at streets is added. 


\subsection{Impacts}

When surveying the impacts of noise on human health and quality of life, not only the level of noise exposition but its duration must also be taken into account, as these impacts accumulate in the human organisms [3]. On the basis of previous laboratory tests on noise nuisance, it is claimed that maximum noise levels show strong correlation with sleep disturbances [27].

According to $64.4 \%$ of the respondents, no health problems associated with noise nuisance have been experienced. Where there were any indicated, they were usually minor, temporary problems and stress, primarily affecting the age groups above 40 years (16.6\% of the age group between 40 and 60 years and $9.5 \%$ of those above 60 years).

The impacts of noise nuisance at night are well indicated by the fact that ca. $60 \%$ of the respondents reported either being occasionally or always disturbed in falling asleep or wakened by various sources of noise (Table 2).

The number of those impacted by a lowered concentration capacity while carrying out work at home is also significant, representing about $40 \%$ of the respondents. Slightly more than one-third of them are impacted by noise nuisance disturbing relaxation at home, while impeding communication is represented with an even less share. Meanwhile the share of those always keeping their windows shut due to the noise experienced is considerably higher (62.6\%) compared to the impacts mentioned above. It should be noted regarding various sources of noise that such are apparent with some regularity, however not permanently.

The results obtained for both cases were correlated with the time since respondents have been living at their present homes. Correlation coefficient for the first case (i.e. impacts on human health) was 0.132 , while that for the impacts on lifestyle varied between -0.144 and -0.042 .

\subsection{Possible solutions}

Noise nuisance experienced at dwellings, according to two-third of the respondents can be abated, whereas $11 \%$ thought it could be abolished. Although, according to almost one-fourth of them it cannot be reduced at all. By right however, according to almost the half of the respondents (47.8\%), no such measures have been taken, while a further $38.4 \%$ were unaware of such. Only the remaining minority reported that recently or previously these types of measures or, at least, attempts were made. Only 28 of the respondents named a specific measure among which lawsuits initiated by the respondents themselves or joint actions by the community of residents should be mentioned while other solutions (e.g. replacement of shut-off devices) were only occasional.

Table 2: Disturbances caused by noise annoyance in the homes of the respondents (\%).

\begin{tabular}{lccc}
\hline $\begin{array}{l}\text { Noise from the street in the respondents' } \\
\text { homes causes: }\end{array}$ & Always & Occasionally & Never \\
\hline Difficulties in falling asleep & 10.0 & 49.2 & 40.7 \\
Sleep disturbances & 10.9 & 50.5 & 38.7 \\
Disturbance during relaxation & 6.8 & 30.3 & 63.2 \\
Disturbance during telephone calls & 2.9 & 16.3 & 80.8 \\
Disturbance during conversations & 3.5 & 16.8 & 79.7 \\
Difficulties in concentration & 6.3 & 35.4 & 58.3 \\
Them to close the windows & 24.2 & 40.6 & 35.2 \\
\hline
\end{tabular}


$68.5 \%$ of the respondents did not know any future measures of this kind proposed, among the remaining answers 'no' is predominating, i.e. the majority did not expect such to take place. According to $61.1 \%$, the problem of noise nuisance is paid enough attention in the town (Fig. 4).

Several preventive (e.g. using more silent vehicles) and passive (i.e. the mitigation of noise during its propagation by, e.g. the construction of noise barriers) ways of noise abatement are known that can be supplemented by a more strict legal background. Noise nuisance related short-or mediumterm community development, transport and land-use planning aims at the establishment of noise-free zones and districts to which pedestrian zones, residential areas and recreational areas are good examples [28].

According to the vast majority of respondents, the primary solution to reduce noise nuisance in the Town of Debrecen is the construction of a ring road (Table 3). In addition to this, the expansion

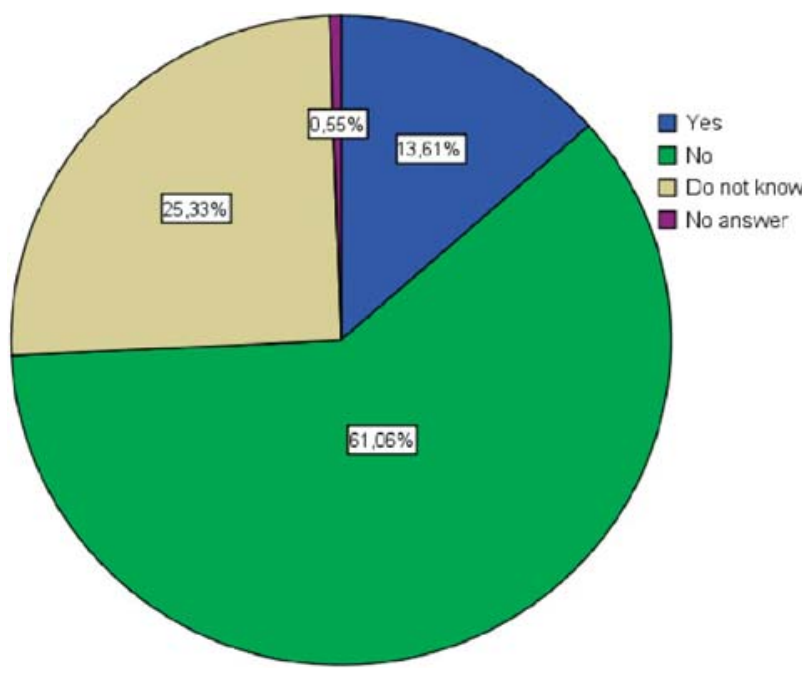

Figure 4: Opinions on noise prevention actions in the town (\%).

Table 3: Opinions on possible measures to solve noise nuisance in the town $(\%)$.

\begin{tabular}{lc}
\hline Measure & $\%$ \\
\hline Construction of a ring-road & 85.4 \\
Expansion of the pedestrian zone of the town & 67.3 \\
$\quad$ centre & 51.7 \\
Time restriction for heavy vehicle traffic & 30.6 \\
Construction of more noise barriers & 35.2 \\
Application of modern shut-off devices & 38.5 \\
Stricter measures & 58.6 \\
Forming green zones within the town & 43.3 \\
Forming silent areas around institutions & 6.3 \\
Other &
\end{tabular}


of the already existing pedestrian zone of the town centre and time restriction for heavy vehicle traffic was emphasised. Stricter measures as well as demands for the application of the classic methods of active noise prevention such as forming more extensive green zones and silent areas are represented by a rather low number of responses.

For the category 'Other', ideas such as the construction of bicycle roads or car-free days were suggested.

\subsection{A summary of results}

According to local people, the Town of Debrecen can be referred to as a noisy Hungarian town. Disturbances caused by road traffic are evident throughout, especially along the main transport routes. The duration of noise nuisance experienced in residential areas is considerable to which must be added noise at the workplaces and in the street. The effects of perceived noise nuisance on the quality of life is represented by occasional or regular (not necessarily frequent) sleep disturbances, primarily among the residents living near roads with severe traffic [10].

\section{POTENTIAL ACTORS TO MANAGE URBAN NOISE AS AN ENVIRONMENTAL CONFLICT}

Environmental noise as a problem is local in terms of its management but is largely non-local in its origins. However, it can be tackled and successfully prevented when thoughtful problem management is implemented at the local and international levels [29]. Moreover, putting forward the principles of subsidiarity and joint responsibility is demanded increasingly by both the EU and the Hungarian legislation [30]. This is well indicated by the 2002/49/EC Directive supporting the necessity of public participation in noise-related issues claiming that 'Member States shall ensure that the public is consulted about proposals for action plans, given early and effective opportunities to participate in the preparation and review of the action plans, that the results of that participation are taken into account and that the public is informed on the decisions taken. Reasonable time-frames shall be provided allowing sufficient time for each stage of public participation' [31].

\subsection{Municipalities}

In addition to the road traffic noise, the so-called 'disco-issue' or the clamour arising from places of entertainment at night combined with the noise of patrons' vehicles is an issue in nearly all municipalities [32]. The results of the survey indicated that more than $70 \%$ of the respondents expected such noise-related disturbances to be solved by the municipality [4] (Fig. 5). However, as mentioned above, the majority of respondents find the present noise prevention actions dissatisfactory.

As revealed by many authors [29, 30, 33] and others, the legal background for noise and vibration prevention in Hungary is basically assured with only some additional measurements lacking.

However, at the present time, municipalities do not have the power to combat these disturbances through legislation, as this power is reserved by central government. In effect, stricter noise abatement regulations than that currently legislated by central government can only be introduced by the municipalities if the actual framework had been previously defined by law or governmental decree. At present, this is not the case [34].

A further default of the present regulation is the dividedness of the magisterial power between inspectorates for the environment and municipalities, impeding joint actions [30]. 


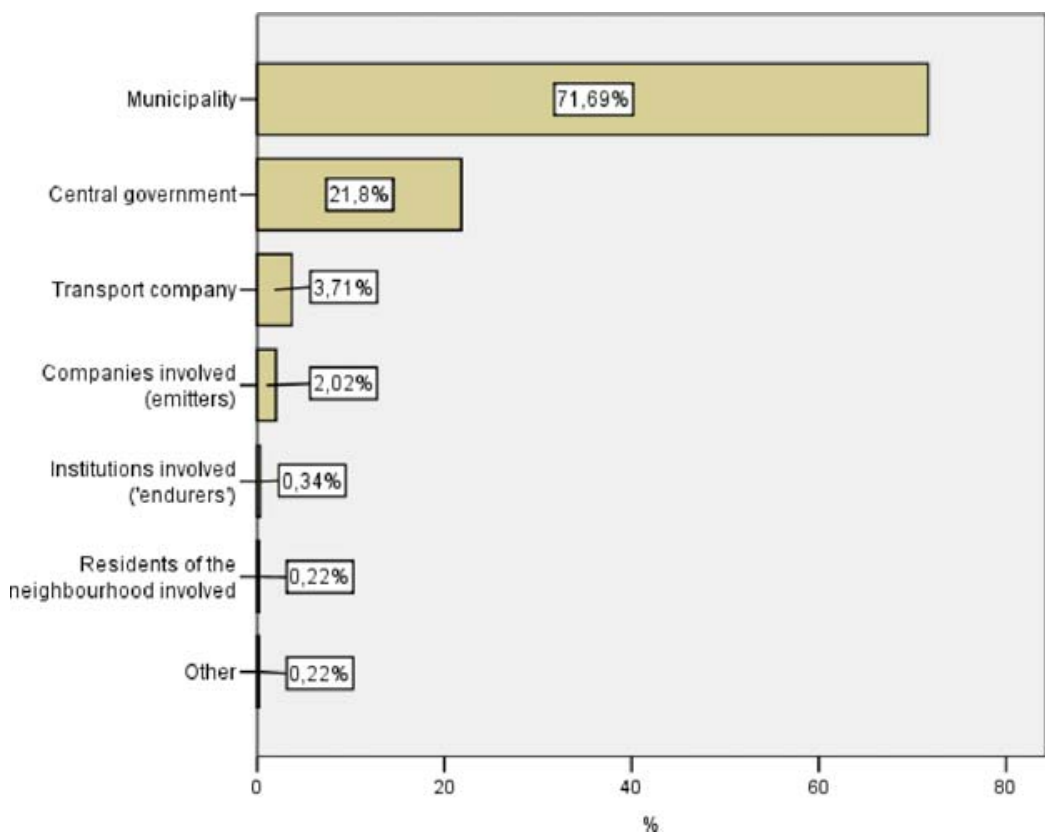

Figure 5: Public opinions on the role of initiator in the management of noise-related problems in Debrecen (\%) [4].

\subsection{Civil organisations}

In Hungary, since the regime change, civil organisations have become relevant social and economic influences active in environmental protection. This is further supported by their role in networking, knowledge and capital. The application of the principle of subsidiarity also underlines the necessity for civil organisations' involvement in the management of the local environmental problems. Despite the above and for a number of other reasons, this social intertwining and division of labour is in its very early stages. It is also evident that, in many cases, civil organisations are regarded as a tool, not as partners by institutes functioning in the field of environmental development [35].

The minimal role of civil organisations is indicated by the fact that they were marked as potential initiators (in the category 'Other') by only approximately $2 \%$ of the respondents [4] (Fig. 5).

\subsection{The individuals}

One of the subjective features of towns is the awareness of the local people [36]. The way residents manage their potentials and problems, how they establish their environment and atmosphere and how they develop their lives is termed as the town's mental infrastructure by Kiss [37]. According to this author, instead of the 'hard', technical factors, the emphasis should be focused on these 'soft' factors in planning, strategy and programme development.

Such alternative strategies based on 'soft' factors can be the basis of bottom-up initiatives in which residents create their own living environment by participation, cooperation with each other and with the aid of professionals. Such joint initiatives can establish community 'life' [5]. 
Worldwide, an increasing number of initiatives focus on growing public participation in environmental impact assessments partly because it has been recognised that dialogue ensures a more detailed knowledge on environmental impacts and can contribute to tackling related conflicts and practical problems [38]. The individual's capacity for participation (i.e., the extent and way of participation) will be, on the one hand, influenced by his/her knowledge on noise nuisance influenced by access to relevant information and his/her level of interest. This latter is influenced by the (individual and community) identity and, as part of it, the level of environmental consciousness (Fig. 1). Prior to structured public involvement, it is important to survey opinions on the relevance of noise nuisance as an environmental problem affecting them. With these data in hand, effective action plans can then be developed. On the basis of the results of the questionnaire survey, the following can be claimed [4]:

a. How important is noise nuisance apparent around the individuals? As claimed earlier in this paper, $74 \%$ of the respondents are disturbed to some extent in their dwellings by noise. Among the impacts of traffic, beside dust and air pollution, noise was reported to be the most annoying.

Finally, to the question whether noise can harm human health, only $7.7 \%$ of the respondents answered 'no' and a further $6.9 \%$ marked 'don't know'. Apparently, they are aware of the consequences and experience them during their every-day lives.

b. How the respondents see their roles in relation to the problem? On the one hand, it is interesting that for transport within the town, 34.5\% use their own car, and $51.9 \%$ use public transport and $15.2 \%$ cycle or walk. This high use of public transport is not due to environmental awareness but rather to low income. Less than half of the respondents $(43.6 \%)$ expressed the intention to minimise noise emissions during their everyday activities. This is a criterion for even fewer (just over 20\%) when purchasing technical appliances. The overall picture is even less encouraging when the individual is seen as the 'endurer' of noise levels, as approximately two-thirds $(61.2 \%)$ make little effort to reduce their exposure to the harmful effects of noise (Fig. 6).

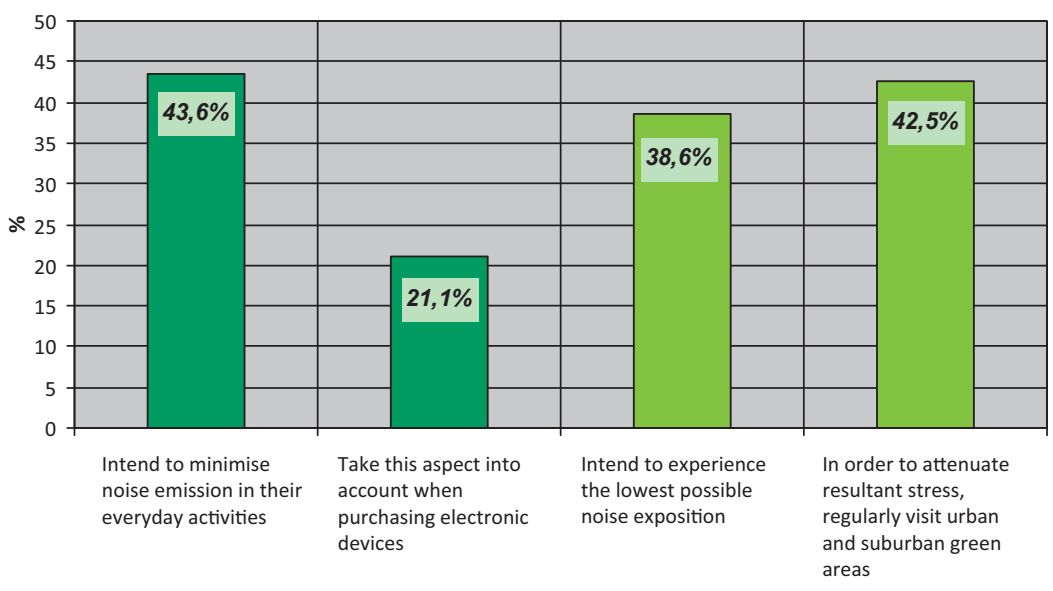

Figure 6: Opinions on the role of individuals (\%). 


\section{PUBLIC PARTICIPATION}

Participation can be ensured in many ways (workshops, round table meetings, Internet forums, etc.); however, formal involvement of the public should be preceded by appropriate information to select affected target groups [15] and a survey of their awareness and sensitivity to noise nuisance (Fig. 1). By being familiar with public opinion, the features and reasons underlying noise-related problems can be systematically explored and followed up by developing strategies to address the most significant and relevant areas of noise abatement. Knowing the attitude of respondents enables those areas where public involvement could be most effective to be defined [4].

The overall picture drawn from the results of the questionnaire survey carried out among the citizens of Debrecen is rather contradictory. Citizens basically perceive the relevance of the issue and are aware of its impacts but they do not recognise their own role in solving it - neither as 'emitters' nor as 'endurers' [4].

A more detailed statistical analysis of the survey data is beyond the scope of this article, and the above discussion is simply a summary of the main conclusions, the aim of which is to emphasise the importance of public participation.

What could be the objectives of such an urban community noise prevention programme? Providing and extending the information on the health impacts of noise, noise-related complaints, noise levels and regulation, learning about a settlement's mental noise maps, strengthening the cooperation of professionals and laymen or even influencing/altering the individual's transport, consumption and behavioural habits. An effective way of achieving an improved noise environment could be the presentation of the advantages resulting from noise abatement, the introduction of improved noise insulation techniques or noise standards for buildings, and, finally, a demonstration of noise nuisance as an externality of transport and, through this, better accounting of the total social costs of transport.

As a consequence of the above, it is important to implement the integration of individual and social responsibility as part of communicative-collaborative urban ecological planning [37]; i.e. as an environmental conflict, noise pollution should be the focus of the highest possible level of public involvement. In this way, the quality of environment, both in the narrow (residential area) and the broader sense (settlement) could be improved, which would contribute to achieving one of the major objectives of urban planning, namely 'a decent quality of life for all' (Fig. 1). By such efforts towards a healthier urban environment, the social dimensions of sustainable development can be significantly strengthened $[39,40]$, in addition to advancing the realisation of a settlement's ecological sustainability (Fig. 1).

\section{REFERENCES}

[1] Nardo, M., Noise Pollution: An overview of management strategies. International Journal of Environmental Technology and Management, 4(4), pp. 300-322, 2004. doi:http://dx.doi. org/10.1504/IJETM.2004.005719

[2] Buna, B., Experiences of noise impact studies in Hungary. Assessment of Environmental Impacts, ed. Gy. Flórián, TEM 13, Közlekedéstudományi Intézet: Budapest, pp. 21-29, 1994 (in Hungarian).

[3] Hatta, L., The Impacts of Noise on Humans, OMIKK Környezetvédelmi füzetek, p. 27, 2000 (in Hungarian).

[4] Baros, Z., Public participation in urban noise prevention. Proceedings of the 2nd Conference on Urban Environment (Debrecen, 27-28th Nov. 2009), Debreceni Egyetem Tájvédelmi és Környezetföldrajzi Tanszék: Debrecen, pp. 94-99, 2009 (in Hungarian). 
[5] Meier, R.L., Ecological Planning, Management, and Design, 2003 - Online manuscript: www. ced.berkeley.edu/pubs/faculty/meier_richard/ecoplanmgmtdes/

[6] Michalkó, G., The Theory and Practice of Urban Tourism, MTA Földrajztudományi Kutató Intézet: Budapest, p. 168, 1999 (in Hungarian).

[7] Juhary-Koroknay, A., The Relationship between the quality of homes and the acoustic comfort. CD-proceedings of the Noise Prevention Seminar - The Actual Issues of Noise Prevention (Debrecen, 8-10th Nov. 2006), OPAKFI, 2006 (in Hungarian).

[8] Penn-Bressel, G., Verkehrslärm und Wohnstandortverhalten. Informationsdienst un Mitteilungsblatt des deutschen Volksheimstättenwerks, 41, pp. 145-148, 1988.

[9] Fodor, I., Environmental Protection and Regionalism in Hungary. Dialóg Campus Kiadó: Budapest-Pécs, pp. 224-235, 2001 (in Hungarian).

[10] Baros, Z. \& Gajdátsy, P., Public opinions on road traffic induced noise nuisance in the Town of Debrecen. Proceedings of the 1st Conference on Urban Environment (Debrecen, 8-10th Nov. 2007), Kossuth Egyetemi Kiadó, Debreceni Egyetem: Debrecen, pp. 134-139, 2008 (in Hungarian).

[11] Eke-Zamárdi, I. \&-Baros, Z., On urban noise - From a conflict theory approach. A Honorary Collection of Studies to Dr. Károly Tar, Magyar Szélenergia Társaság, pp. 119-127, 2007 (in Hungarian).

[12] Herzog, T.R., A cognitive analysis of preference for urban nature, Journal of Environmental Psychology, 9, pp. 27-43, 1989. doi:http://dx.doi.org/10.1016/S0272-4944(89)80024-6

[13] World Bank, Cities in Transition. World Bank Urban and Local Governments Strategy, World Bank: Washington, 2000.

[14] Butters, C., A Holistic Method of Evaluating Sustainability, 2004. Online. www.gaiaoslo.no/ artikler.html

[15] Bonacker, M., Participation process according to Directive 2002/49/EC. CD-proceedings of Forum Acusticum (Budapest, 29th Aug-2nd Sept 2005). Budapest, 2005 (in Hungarian).

[16] Nagy, B., Settlement, the Built World, GEO-Könyvek, B+V (medical\&technical) Lap- és Könyvkiadó Kft., 486 p, 2005 (in Hungarian).

[17] Holden, E., Ecological footprints and sustainable urban form. Journal of Housing and the Built Environment, 19(1), pp. 91-109, 2004. doi:http://dx.doi.org/10.1023/ B:JOHO.0000017708.98013.cb

[18] Kang, J., Urban Acoustics. Applied Acoustics, 66, pp. 121-122, 2005. doi:http://dx.doi. org/10.1016/j.apacoust.2004.07.006

[19] Wilkins, H., The need for subjectivity in EIA: discourse as a tool for sustainable development. Environmental Impact Assessment Review, 23, pp. 401-414, 2003. doi:http://dx.doi. org/10.1016/S0195-9255(03)00044-1

[20] Steinemann, A., Rethinking human health impact assessment. Environmental Impact Assessment Review, 20, pp. 627-645, 2000. doi:http://dx.doi.org/10.1016/S0195-9255(00)00068-8

[21] Kneip R. Transport and the quality of life - controversy or harmony? Proceedings of the 2nd Conference on Urban Environment (Debrecen, 27-28th Nov. 2009), Debreceni Egyetem Tájvédelmi és Környezetföldrajzi Tanszék: Debrecen, pp. 128-133, 2009 (in Hungarian).

[22] Locsmándi, G., Urban Planning and Environmental Protection, Supplemental Study. Háttértanulmány, Nemzeti Kutatási és Technológiai Hivatal, A természeti és épített környezet védelme és fejlesztése munkacsoport, p. 12, Online www.nkth.gov.hu/innovaciopolitika/technologiai/ termeszeti-epitett (in Hungarian) 
[23] Leipzig Charter on Sustainable European Cities (2007) - adopted by the informal meeting of the Council of Ministers in Leipzig on 24 May 2007. http://www.eu2007.de/en/News/download_docs/Mai/0524-AN/075DokumentLeipzigCharta.pdf

[24] Bulla, M., Environmental key problems. The Urban Environment of Hungary, ed. Gy. Enyedi, Magyar Tudományos Akadémia: Budapest, pp. 187-236, 2000 (in Hungarian).

[25] Baros, Z., Public opinions on road traffic induced noise in residential areas with various builtup types in the Town of Debrecen. CD-Rom Proc of the 3rd International Conference on the application of sciences, technology and economics (Szombathely, 30th October 2004), Berzsenyi Dániel Föiskola: Szombathely, p. 8, 2005 (in Hungarian).

[26] Szász, G. \& Tökei, L. (eds). Meteorology for Agronomists, Horticulturists and Foresters, Mezőgazda Kiadó, pp. 697-703, 1997 (in Hungarian).

[27] Andersson, K.-Lindvall, T. (eds), Health Effects of Community Noise, Nordic Noise Group, Nordic Council of Ministers, p. 45, 1988.

[28] European Commission, Inventory of Noise Mitigation Methods - The European Commission Directorate-General: Environment Policy Area: Noise, Working Group 5: Abatement, p. 46 Online. www.a21italy.it/enviplans/guidelines/reading/noise/mitigations_02_en.pdf

[29] Bite, P. \& Póta Gy., EU Guidelines and their enforcement in the traffic induced noise prevention in Hungary. Közlekedéstudományi Szemle, 51(7), pp. 241-256, 2001 (in Hungarian).

[30] Hungarian Academy of Sciences, Section of Engineering Sciences, Complex Committee of Acoustics, Environmental Noise Prevention in Hungary and its Development Strategy with Special Focus on the EU Requirements, Budapest, p. 45, 2003 (in Hungarian).

[31] Directive 2002/49/EC of the European Parliament and of the Council of 25 June 2002 relating to the assessment and management of environmental noise - http://eur-lex.europa.eu/LexUriServ/LexUriServ.do?uri=OJ:L:2002: 189:0012:0025:EN:PDF

[32] Dávid, L. et al. (ed), The Environmental Programme of the North Great Plain Region in Hungary, Észak-alföldi Regionális Fejlesztési Ügynökség: Debrecen, p. 150, 2003 (in Hungarian).

[33] Berndt M., Detailed background information to the implementation of the Governmental Decree No. 280/2004 on the assessment and management of environmental noise. Budapest, p. 12, 2007 (in Hungarian).

[34] Vizeli, S., The Role of Municipalities in Noise Prevention. CD-proceedings of the Noise Prevention Seminar - The Actual Issues of Noise Prevention (Debrecen, 8-10th Nov. 2006), OPAKFI, 2006 (in Hungarian).

[35] Bucher, E., Civil Organisations for the Development of the Urban Environment - with examples from the County of Baranya. CD-proceedings of the 3rd Hungarian Conference of Geography (Budapest, 6-7th Sept. 2006), 2006 (in Hungarian).

[36] Bujdosó, Z., The urbanization in Hungary during the last decade- is it an economic interest or a question of prestige to be graded a town in our country nowadays? Cross-Border Co-operations Schengen Challenges, ed. I. Süli-Zakar, Kossuth Egyetemi Kiadó: Debrecen, pp. 232-237, 2004.

[37] Kiss, A., Conscious Urban Development. Landscape, Environment and Society - Honorary Studies for Prof. Ilona Kevei-Bárány: Szeged, pp. 363-372, 2006 (in Hungarian).

[38] Soneryd, L. \& Weldon, S., Noise and newts: Public Engagement in the UK and Sweden. Environmental Impact Assessment Review, 23, pp. 17-37, 2003. doi:http://dx.doi.org/10.1016/ $\underline{\text { S0195-9255(02)00057-4 }}$

[39] Swedish Council for Sustainable Development (SCSD). Make Your Municipality Sustainable (An Introduction to Local Tools and Working Methods for Sustainable Development). Online. www.hallbarhetsradet.se/upload/publikationer/Make_your_muni_webb.pdf

[40] Puczkó, L. \& Rátz, T., The Impacts of Tourism - An Introduction. Häme Polytechnic: Finland, p. 406, 2002. 